\title{
Dry matter yield of six legume species in response to lime over 3 years at Glenmore Station, Mackenzie Basin
}

\author{
S. BERENJI ${ }^{1}$, A. MILLS ${ }^{1}$, J.L. MOIR ${ }^{1}$, K.M. POLLOCK ${ }^{1}$, \\ W. MURRAY ${ }^{2}$, E. MURRAY ${ }^{2}$ and D.J. MOOT ${ }^{1}$ \\ ${ }^{1}$ Field Research Centre, Faculty of Agriculture and Life Sciences, \\ PO Box 85804, Lincoln University, Lincoln \\ 7647, Christchurch, New Zealand \\ ${ }^{2}$ Glenmore Station, Lake Tekapo, New Zealand \\ samagro@gmail.com
}

\begin{abstract}
The production and persistence of legumes which may improve South Island high-country pasture in the Mackenzie Basin were studied. The initial soil test results confirmed toxic levels of aluminium (9 $\mathrm{mg} / \mathrm{kg}, \quad 0-150 \mathrm{~mm}$ soil depth) that has prevented the development of large areas of land traditionally grazed by merino sheep and beef cattle. A 3-year field experiment was direct-drilled in December 2012 with five rates $(0,0.5,1,2$, and $4 \mathrm{t} / \mathrm{ha})$ of surface applied lime and six legumes (lucerne, 'Russell' lupin, Caucasian clover, white clover, balansa, and Lotus pedunculatus) in three replicates. In Year 1, balansa clover and Russell lupin were the highest yielding legumes ( $7 \mathrm{t} \mathrm{DM} / \mathrm{ha})$, regardless of lime application rates. In Year 2 'Russell' lupin was the highest (10.4 $\mathrm{t} \mathrm{DM} / \mathrm{ha})$. Caucasian clover produced $4.6 \mathrm{t} \mathrm{DM} / \mathrm{ha}$ and white clover and lucerne around $4.0 \mathrm{t} \mathrm{DM} / \mathrm{ha}$. Balansa clover $(1.4 \mathrm{t}$ $\mathrm{DM} / \mathrm{ha}$ ) and Lotus pedunculatus (2.5 t DM/ha) were the lowest yielding and they did not recover or persist after the initial grazing by merino sheep. These results confirmed that 'Russell' lupin and Caucasian clover thrived without the application of lime in this acidic soil with high Al levels.
\end{abstract}

Keywords: Caucasian clover, Dactylis glomerata, lucerne, Lotus pedunculatus, Lupinus polyphyllus, Medicago sativa, 'Russell' lupin, soil aluminium, Trifolium ambiguum

\section{Introduction}

The South Island high-country has been the most extensively farmed area in New Zealand for over 150 years. Historically, merino sheep have been farmed for their fine wool. They spend summers grazing high mountain grassland and are then mustered to the lower country for winter feeding and lambing. To maintain, and potentially increase the wool production off these farms, potential pasture options were investigated. The key requirement is to improve dryland pasture and, therefore, animal production through introduction of appropriate legumes that can overcome the major nitrogen deficiency (Moot 2012). The most successful intervention has been expansion of lucerne (Medicago sativa) grazing on lower altitude land (Anderson et al. 2014). However, large areas of the South Island high-country contain highly acidic soils with limited opportunity to alleviate that problem with lime. In addition, these soils may contain toxic levels of aluminium (Scott et al. 1995; Moir \& Moot 2010) that prevent lucerne survival. To overcome these constraints several legume species have been tested in the region (Harris et al. 1973; Davis, 1981a, b; Scott et al. 1995; Scott 1998; Caradus et al. 2001), but uptake of recommended species has been low.

Research has continued to identify suitable legume species for this environment (Scott 2001). The focus has been on overcoming high levels of soil aluminium (Moir \& Moot 2010; Moir \& Moot 2014; Berenji et al. 2015; Whitley et al. 2018) that inhibit root growth and nitrogen fixation, nodulation and survival of rhizobia strains (Ryan-Salter et al. 2014; Andrews et al. 2015; Black et al. 2015; Berenji et al. 2017). Potentially, lime injected at depth, rather than surface applied, could address the low soil $\mathrm{pH}$ and $\mathrm{Al}$ toxicity (Hendrie et al. 2018), but this invasive technology is currently unproven on a large scale. In an attempt to overcome these problems, Moot \& Pollock (2014) assessed the potential of the ubiquitous perennial lupin (Lupinus polyphyllus) to survive and thrive in this environment. Their sowing rate experiment at Glenmore Station showed lupins contributed $79 \%$ of annual yield with up to $10 \mathrm{t} \mathrm{DM} /$ ha in the second year. In parallel, six legume species were sown at the same experimental site but with the addition of five rates of surface applied lime. The aim was to compare the production and persistence of these species under these challenging conditions. Ultimately, success is achieved if the research leads to on-farm adoption of the most suitable legumes.

\section{Methodology and analysis}

Previous studies at the Glenmore Station (Moot et al. 2013) showed poor seedling survival of the sown legumes without the removal of resident vegetation. 


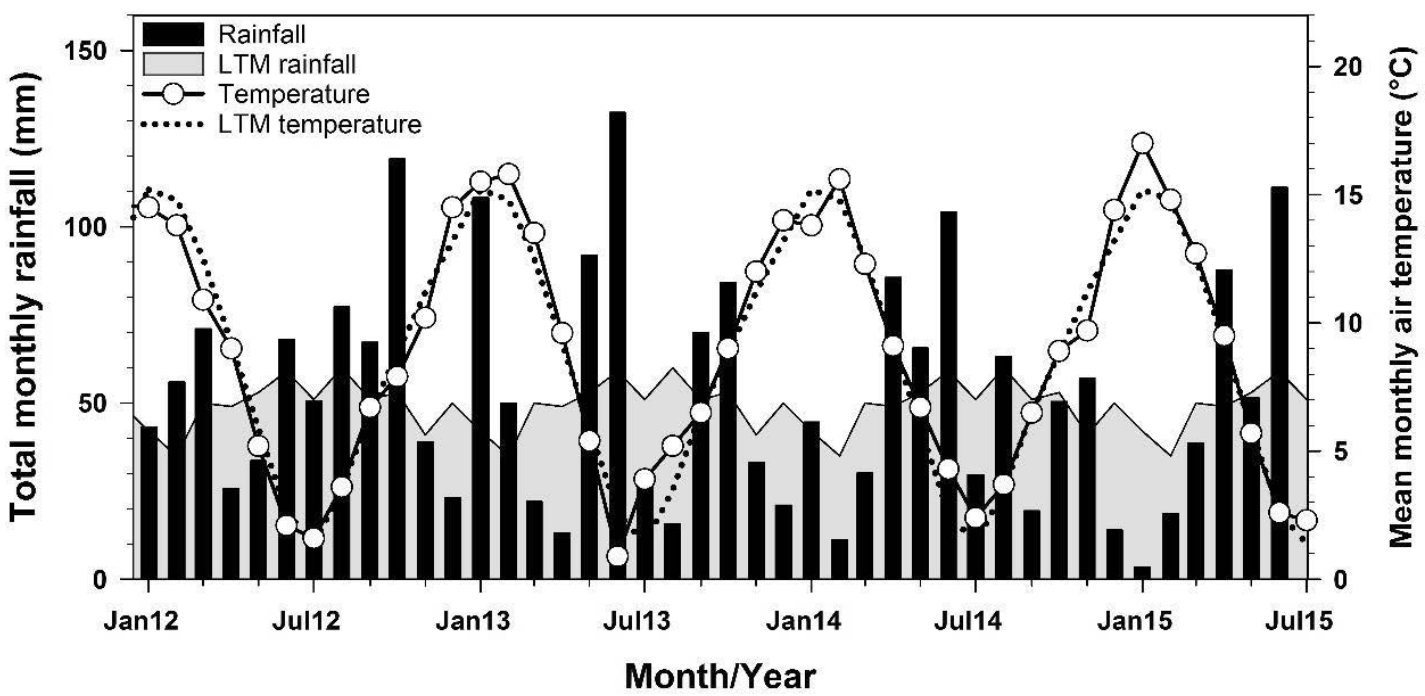

Figure 1 Monthly average temperatures $\left({ }^{\circ} \mathrm{C}\right)$ and total rainfall $(\mathrm{mm})$ recorded on site at Glenmore Station, and long-term mean (LTM) data for Tekapo (NIWA CliFlo Database, accessed August 2015).

Therefore, a "double spray" technique was applied (Moot \& Pollock 2014). The resident vegetation was sprayed with glyphosate (3.6 kg a.i./ha) in March 2012, then burnt. Pelleted Aglime was surface applied on the 1st May 2012. Glyphosate (1.44 kg a.i./ha) was applied again in early December 2012.

The experiment was conducted at Glenmore Station $\left(43^{\circ}, 54^{\prime}, 7.86^{\prime \prime} \mathrm{S} 170^{\circ}, 28^{\prime}, 19.52^{\prime \prime} \mathrm{E}, 720 \mathrm{~m}\right.$ a.s.1.) as a 5 x 6 strip-plot design in three replicates. Pelleted Aglime was surface applied at five rates $(0,0.5,1,2$, and $4 \mathrm{t} / \mathrm{ha})$ on 1st May 2012 to 6 x 28 m strips. Six legume species, lucerne 'Force 4', Caucasian clover 'Endura' (Trifolium ambiguum), 'Russell' lupin (Lupinus polyphyllus), white clover 'Nomad' (Trifolium repens), balansa clover 'Bolta' (Trifolium michelianum) and lotus 'Trojan' (Lotus pedunculatus) were drilled into $4.67 \times 30.0 \mathrm{~m}$ strips across the five lime strips on 11 December 2012, using a Flexiseeder drill designed to cope with uneven surfaces. Individual plot sizes were $4.67 \times 6.0 \mathrm{~m}$. All seeds were inoculated with their specific commercial peat inoculant, one day before sowing.

Temperature and rainfall were recorded on-site from December 2011. The long-term (1981-2010) means for rain and temperature are included in Figure 1. For 2012-2013, monthly rainfall was typically variable and at times differed greatly from long-term averages. A dry December was followed by an $80 \mathrm{~mm}$ rain event at the beginning of January 2013, 4 weeks after sowing. This rainfall and conserved moisture from the spring fallow provided better than average moisture conditions through to autumn 2013.

For the 2013-2014 season, heavy rain and snow in June 2013, followed by sufficient rain in July-
September meant soils started spring at field capacity. November 2013-March 2014 was drier than normal, but not atypically so. The 2014-2015 season started with a cold July but a full soil water profile after higher than average rain in April-June, 2014. The rest of winter and spring had average temperatures ending with a cool November.

The soil at the experimental site is classified as Orthic Brown according to New Zealand Soil Classification (Hewitt 1992). A full soil nutrient analysis was conducted before the start of the field experiments in November 2011 (Table. 1). Soil samples were taken by $75 \mathrm{~mm}$ soil corers, bulked and a subsample sent for

Table 1 Pre-experiment soil $(0-75 \mathrm{~mm})$ nutrient results sampled in Novemeber 2011 at Glenmore Station, Lake Tekapo, Mackenzie Basin.

\begin{tabular}{lcc}
\hline Soil properties & Level & $\begin{array}{c}\text { Optimum range } \\
\text { for legumes }\end{array}$ \\
\hline $\mathrm{pH}_{\text {water }}$ & 5.1 & $5.8-6.3$ \\
Olsen Phosphorus (mg/L) & 15 & $20-30$ \\
Sulphate sulphur (mg/kg) & 23 & $7.0-15$ \\
Potassium (me/100g) & 0.54 & $0.5-0.7$ \\
Calcium (me/100g) & 2.8 & $6.0-12$ \\
Magnesium (me/100g) & 0.86 & $1.0-3.0$ \\
Sodium (me/100g) & 0.15 & $0.2-0.4$ \\
CEC (me/100g) & 15 & $12-25$ \\
Total Base Saturation (\%) & 28.2 & $55-75$ \\
Aluminium* (mg/kg) & 8.9 & 0.0 \\
\hline
\end{tabular}

${ }^{*} \mathrm{CaCl}_{2}$ extractable. 


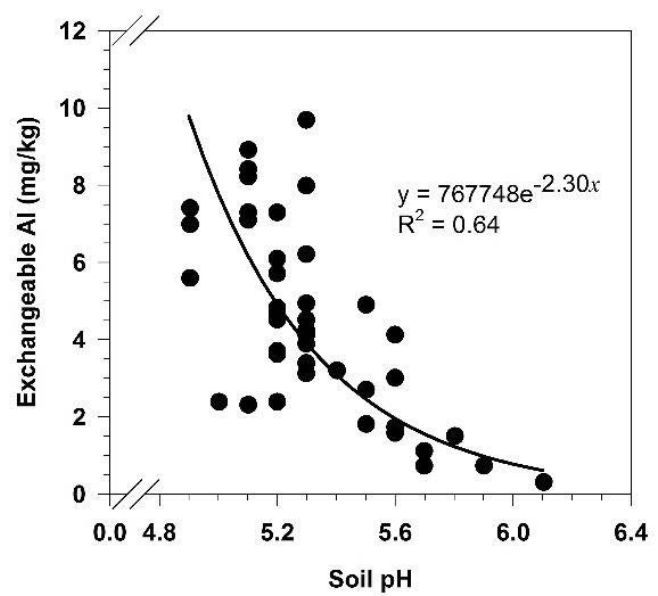

Figure 2 Summary of soil exchangeable Al ( $\mathrm{mg} / \mathrm{kg})$ against soil $\mathrm{pH}$ at Glenmore Station from measurements inside and outside the field experiments from December 2011 to March 2013.

analysis. The topsoil had a $\mathrm{pH}$ of 5.1 and $\mathrm{Al}$ content of $8.9 \mathrm{mg} / \mathrm{kg}$ of soil.

Soil samples (0-75 $\mathrm{mm}$ and 75-150 mm, soil depth) were also taken in November and December 2012 and March 2013, using $2.5 \mathrm{~cm}$ diameter corers.

The experiment was grazed for 2 days in mid-June 2013 by 800 merino ewes. Quadrat cuts and botanical separation occurred three times in Year 1, four times in Year 2 and four times in Year 3. Lucerne plots were also harvested for DM yield on 20th October 2013 followed by mowing to $5-10 \mathrm{~cm}$ to promote a 6-7 week regrowth cycle for the lucerne. The whole paddock ( $2 \mathrm{ha}$ ) was grazed again from 6-9th December 2013, and then by 200 ewes for 7 days at the end of March 2014, and for 2 days in November 2014 after the spring DM yield assessment.

Seedling populations of the sown legumes were counted 42 and 86 days after sowing. The percentage of nodulated plants was estimated for lucerne, lupin and Caucasian clover on 7th March 2013 (86 days after sowing) and again in mid-March 2015 by excavating 10 randomly selected plants/lime treatment/replicate. The accumulated yield (t DM/ha/year) for sown legumes was analysed as a strip-plot (criss-cross) by analysis of variance (ANOVA) using Genstat version 14 statistical software. Mean values were compared using Fisher's protected $\mathrm{LSD}_{5 \%}$.

\section{Results}

Exchangeable Al levels $(\mathrm{mg} / \mathrm{kg})$ were influenced by soil $\mathrm{pH}$ (Figure 2). Al levels were highly variable over the experimental site, especially in soils with a $\mathrm{pH} \leq 5.6$.

Seven months after the lime application, the $\mathrm{pH}$ was unaffected by lime rates, except in the surface (0-75 $\mathrm{mm}$ ) after $4 \mathrm{t} / \mathrm{ha}$ of lime was applied which increased

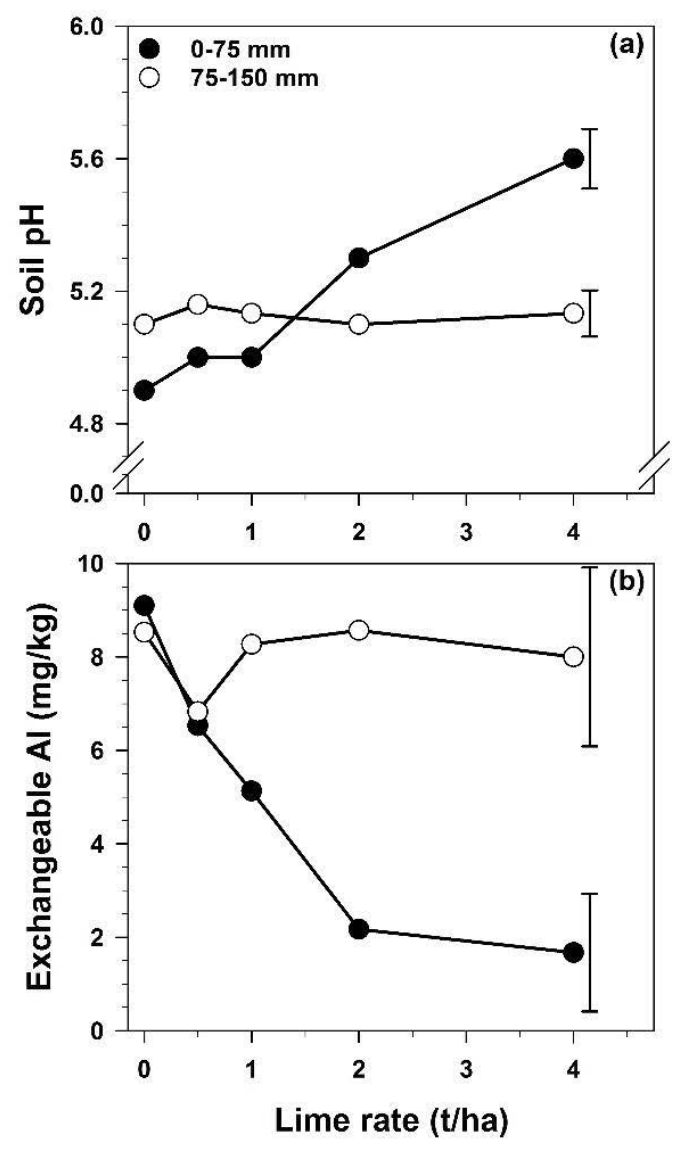

Figure 3 (a) Soil $\mathrm{pH}$ and (b) exchangeable $\mathrm{Al}(\mathrm{mg} / \mathrm{kg})$ in response to the application of lime at Glenmore Station on 1st May 2012. Soil samples (0-75 $\mathrm{mm}$ and $75-150 \mathrm{~mm}$, soil depths) were taken in November 2014. Error bars indicate least significant differences of means $\left(\mathrm{LSD}_{5 \%}\right)$.

the $\mathrm{pH}$ from 5.2 to 5.7. The $\mathrm{Al}$ content decreased to 1.5 $\mathrm{mg} / \mathrm{kg}$ in the top $75 \mathrm{~mm}$ of soil by applying $4 \mathrm{t}$ lime/ha. In November 2014 (30 months after lime application) the $2 \mathrm{t} / \mathrm{ha}$ of applied lime increased the soil $\mathrm{pH}$ and decreased the exchangeable aluminium (Figure 3 ).

The availability of phosphorus $(\mathrm{mg} / \mathrm{L})$ in top-soil $(0-$ $75 \mathrm{~mm}$ ) was affected $(\mathrm{P}<0.01)$ by lime rates (Figure 4 , $\left.\mathrm{R}^{2}=0.90\right)$. An Olsen $P$ of $14 \mathrm{mg} / \mathrm{L}$ was measured in the control (no lime) and this increased to $20 \mathrm{mg} / \mathrm{L}$ with 1 $\mathrm{t} / \mathrm{ha}$ of surface applied lime and to a maximum of 24 $\mathrm{mg} / \mathrm{L}$ with $2 \mathrm{t} / \mathrm{ha}$ applied.

Seedling populations of the sown legumes were not different $(\mathrm{P}=0.22) 42$ and 86 days after sowing (Figure $5)$ and were also unaffected ( $>0.32)$ by lime treatment.

Accumulated dry matter (DM) yield differed $(\mathrm{P}<0.001)$ among the sown legumes in Year 1 (20122013), Year 2 (2013-2014) and Year 3 (2014-2015). 


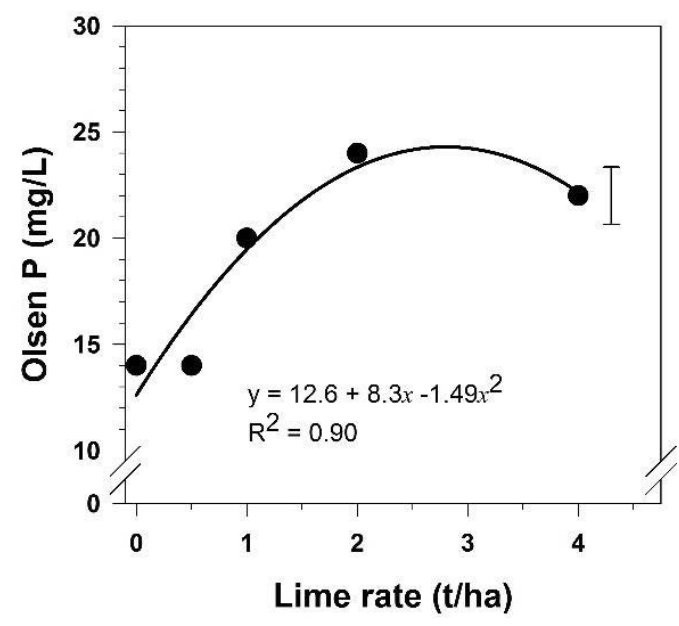

Figure 4 Olsen $\mathrm{P}(\mathrm{mg} / \mathrm{L})$ response to surface applied lime on 1 st May 2012 at Glenmore Station. Error bar indicates the standard error of the mean (SEM= 2.7). Topsoil samples $(0-75 \mathrm{~mm})$ were taken using a $2.5 \mathrm{~cm}$ diameter corer in December 2012.

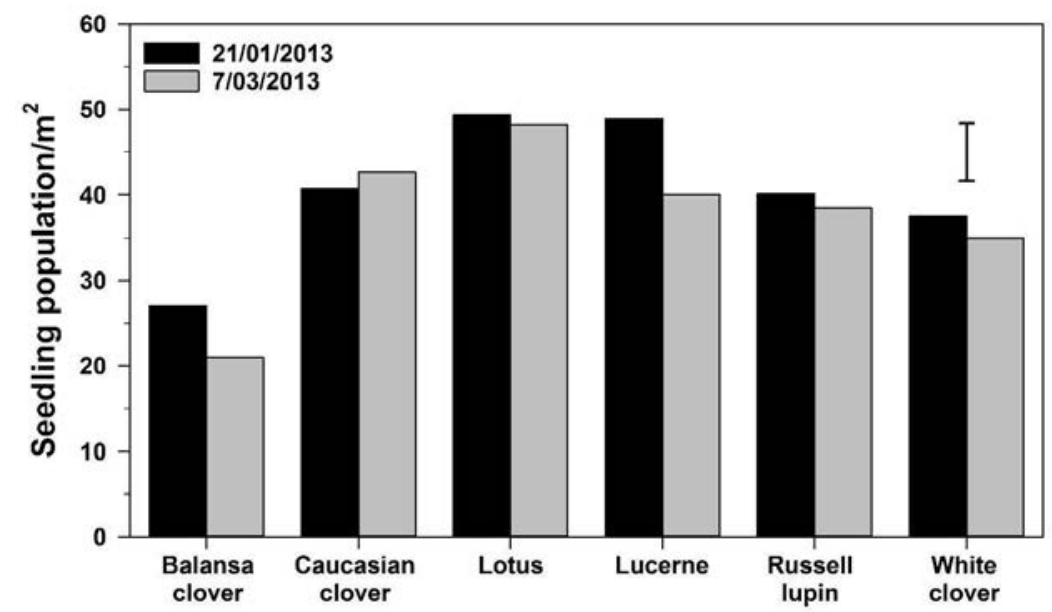

Figure 5 Seedling population $\left(/ \mathrm{m}^{2}\right)$ of the sown legumes 42 and 86 days after sowing on 11 th December 2012 at Glenmore Station. The error bar indicates the standard error of the mean for the sown legumes $(\mathrm{SEM}=6.7), \mathrm{LSD}_{5 \%}=22$.

Within Year 1, 'Russell' lupin yield (4.3 t DM/ha) exceeded other sown legumes in March 2013, 3 months after sowing. The other sown legume species yielded $\leq$ $2 \mathrm{t} \mathrm{DM} /$ ha (Figure 6). Caucasian clover had the lowest DM yield and slowest establishment within these first 3 months. By April 2013, the DM yield of balansa clover ( $7.8 \mathrm{t} / \mathrm{ha}$ ) exceeded the $6.0 \mathrm{t} / \mathrm{ha}$ for 'Russell' lupin. The accumulated DM for lucerne was $4.5 \mathrm{t} / \mathrm{ha}$ which was comparable with Caucasian clover, lotus and white clover.

In Year 2, 'Russell' lupin yielded $10.4 \mathrm{t} \mathrm{DM} / \mathrm{ha}$, which was the highest $(\mathrm{P}<0.001)$ of the sown legumes. Balansa clover and lotus with 1.0 and $2.2 \mathrm{t} \mathrm{DM} / \mathrm{ha}$ of accumulated yield, respectively, were lower yielding than other legume species, and did not persist beyond Year 2. In Year 3, 'Russell' lupin produced 4 t DM/ha and Caucasian clover $1.5 \mathrm{t} \mathrm{DM} / \mathrm{ha}$. Lucerne and white clover produced 0.7 and $1.0 \mathrm{t} \mathrm{DM} / \mathrm{ha}$, respectively. Yield of the sown legumes was unaffected $(\mathrm{P}>0.42)$ by lime rates over time. Low December-February rainfall meant the soil dried quickly with the onset of higher than normal summer temperatures and pastures were moisture stressed. Thus, spring growth was high for the initial grazing, but the summer regrowth was minimal.

'Russell' lupin remained the most dominant sown legume in March, October and December 2013, with the highest $(\mathrm{P}<0.001)$ herbage content $(88 \%$ of $\mathrm{DM})$ among the sown legumes (Moot et al. 2015). White clover content was $60 \%$ in sown plots. Fifteen months after sowing the contents of sown legume differed $(\mathrm{P}<0.001)$ among species. 'Russell' lupin content was $50 \%$ and remained the most dominant species. Sown balansa, lotus, lucerne, and Caucasian clover contents ranged from 7.3 to $12 \%$.

The percentage of nodulated plants was affected $(\mathrm{P}<0.01)$ by a species $\mathrm{x}$ lime interaction at establishment. When measured 86 days after sowing (Figure 7a), 'Russell' lupin had $>90 \%$ nodulation at all lime rates. In contrast, the percentage of nodulated plants increased with lime rates for lucerne and Caucasian clover $(40 \%$ in the control to $70-85 \%$ with the $4 \mathrm{t} /$ ha of applied lime). By March 2015 there were only a few lucerne plants to sample and only in the 2 and $4 \mathrm{t} / \mathrm{ha}$ lime treatments. Of these, only $10 \%$ of the lucerne plants had nodules. For 'Russell' lupin there was still $>90 \%$ nodulation $(\mathrm{P}<0.001)$ with about $60 \%$ in Caucasian clover regardless of lime rate (Figure 7b).

\section{Discussion}

To maintain the financial viability of traditional sheepbased merino wool farming in the Mackenzie district solutions are required to improve their profitability. Based on the current research, the introduction of perennial lupins and Caucasian clover offers a low-cost opportunity to improve pasture and animal productivity. These two species were the only ones to survive and thrive after 3 years in the environment. Other 
researchers have previously recommended their use as pastoral species in this environment (Scott et al. 1995; Scott 1998; Moot \& Pollock 2014), but to date their acceptance into farm systems has been limited. For Caucasian clover, an inability to source seed at low cost (Monk et al. 2016) and difficult establishment (Black et al. 2014a) have limited its introduction, despite previous reports of success and persistence (Allan \& Keoghan 1994). The slow establishment of Caucasian clover has been recognised for many years (Scott 1998) due to preferential partitioning of assimilate to roots (Thomas 2003) thus a long period between seedling emergence and secondary leaf production (Black et al. 2002). However, establishment methods to successfully establish Caucasian clover have been offered (Moorhead et al. 1994) and Caucasian clover is used in some lowland areas to add to the total legume content. Success has come from establishment as a monoculture or with other slow emerging species (Hurst et al. 2000) which suggests cocksfoot (Moot et al. 2000) may be a suitable companion plant. In the current experiment, Caucasian clover was slow to establish with a low yield in its first year (Figure 6), but by Year 3 it was the second most productive species. Of importance was its lack of response to lime, which suggests it will thrive in a low input environment. However, the highly variable $\mathrm{pH}$ and aluminium status across the site (Figure 2) indicates the application of 1 $\mathrm{t} / \mathrm{ha}$ of lime to aid nodulation would be prudent. Over time the Caucasian clover is likely to increase in area and production and become a productive and persistent legume capable of fixing nitrogen encouraging the growth of associated species (Scott 1998).

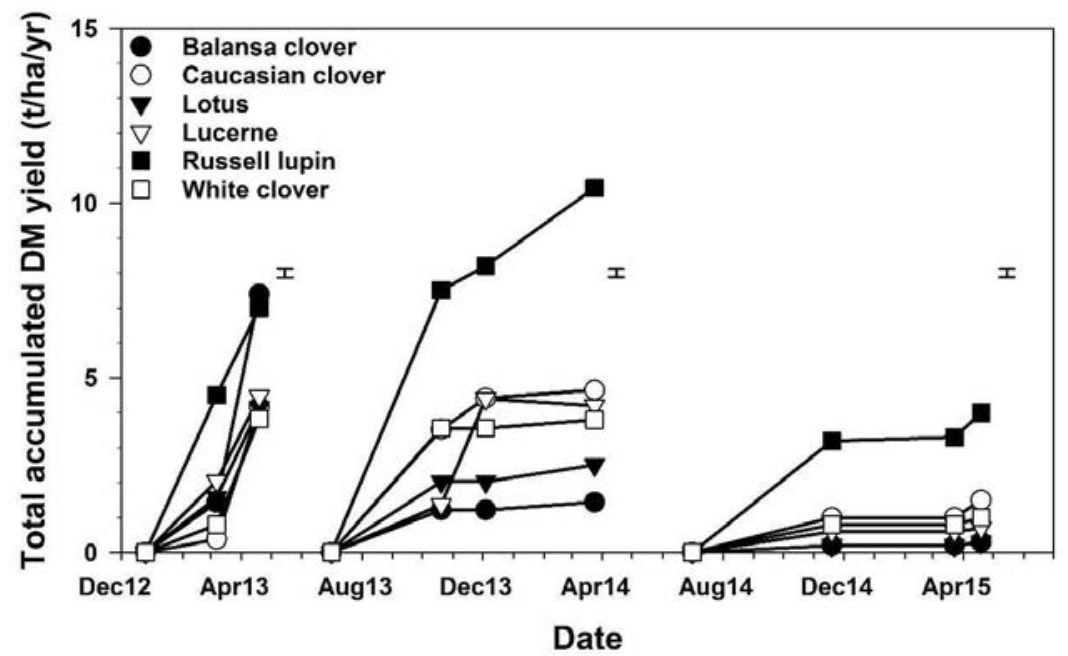

Figure 6 Accumulated annual yields (t DM/ha/year) for sown legumes at Glenmore Station. Error bars indicate the maximum standard error of the mean for annual DM yield (2012-2013: SEM=0.26, LSD $5 \%=0.82 ; 2013-2014:$ SEM $=0.24, L_{5} D_{5 \%}=1.01 ; 2014-$ 2015: SEM=0.25, LSD $_{5 \%}=0.77$ ).

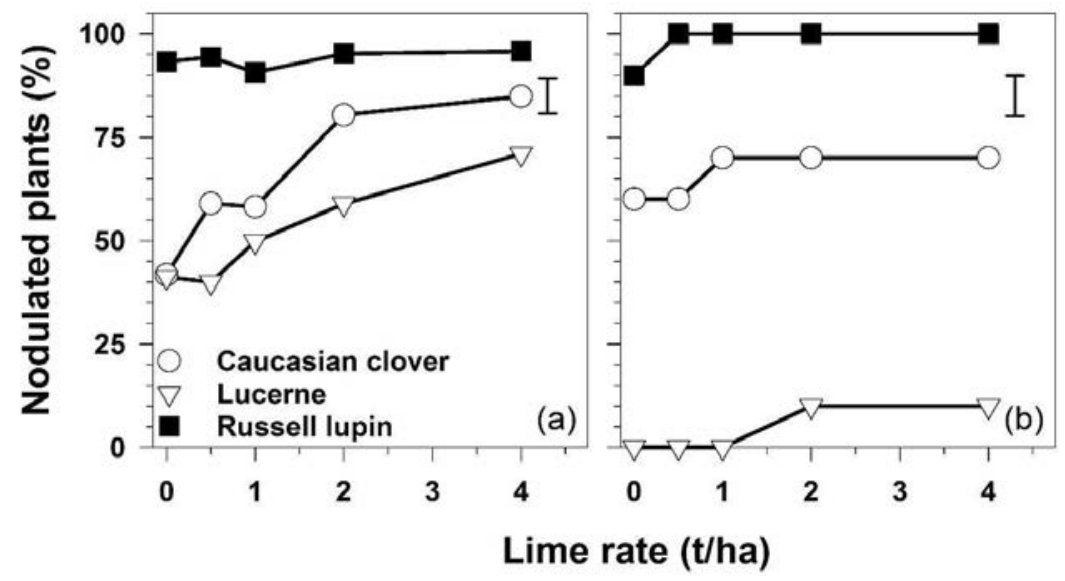
clover and 'Russell' lupin in March 2013 (a) and March 2015 (b). Error bar indicates

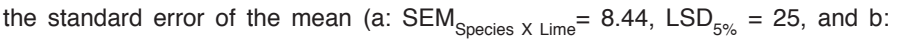
SEM $_{\text {Species }}=9.78, \operatorname{LSD}_{5 \%}=27$ ).

The introduction of 'Russell' lupin as a grazing species has an equally long advocacy, particularly from the long-term trials managed by Dr David Scott (Scott 1989). However, the role of 'Russell' lupin in the high-country has also courted controversy (Wardell 2016) and needs to be managed within constraints. The greatest opposition to perennial or 'Russell' lupin stems from its presence in gravel-lined rivers providing cover for predatory mustelids. Therefore, the advocacy of planting lupins comes with a caveat to ensure riverbed areas are kept clear. In our experimental blocks there was no evidence of accidental spread of the lupins into the surrounding paddocks. Equally, roadside 
plantings from 50 years ago have made little incursion into adjacent paddocks without mechanical or human intervention. The benefits of lupins to the farm system have been noted (Black et al. 2014b) for dry areas of the Mackenzie Basin but this is the first time they have been used to populate high aluminium soils in a high rainfall area. Their ability to survive and thrive has been shown by their high yields in each year, supporting previous results (Moot \& Pollock 2014). Sheep grazing the experimental area consumed all lupin plants, particularly when they were in flower.

A feature of 'Russell' lupin was the high level of nodulation found at both sampling dates (Figure 7). The ability of lupin rhizobia to overcome this high aluminium soil environment and nodulate plants wherever they grow (Ryan-Salter et al. 2014) suggests 'Russell' lupin is widely adapted and likely to thrive where other legumes cannot. This was highlighted by the comparison with lucerne. The lucerne initially established an adequate population of nodulated plants that was enhanced by the addition of lime (Figure 7a). However, by the third year few lucerne plants had survived and those that had were poorly nodulated, and only with 2 and $4 \mathrm{t} / \mathrm{ha}$ of lime rates. The difference in species responses may reflect the symbiotic relationship with the roots of both plants. The rhizobia in lupin appeared to form a permanent nodule that became hard and almost enclosed in a callus-type material. This could be providing the rhizobia with protection from adverse soil conditions, aiding their survival. For lucerne the nodulation process appeared more dynamic. The presence or absence of lucerne nodules appeared more responsive to other factors since these rhizobia need to be able to survive for long periods in a free-living state in the soil. Recent Australian work to select aluminium tolerant rhizobia (Wigley et al. 2018) offers an opportunity to test this theory in the high-country. The inability of the surface applied lime to change the $\mathrm{pH}$ below $75 \mathrm{~mm}$ depth (Figure 3) suggests more radical interventions, such as liming down the profile (Hendrie et al. 2018), may be required if lucerne is to be established in the current circumstances. Of note was the fact that $1 \mathrm{t} / \mathrm{ha}$ of surface applied lime increased the Olsen P (Figure 4 ), which would support legume growth, and it is therefore recommended for a commercial situation. This suggests the historic phosphate application onsite has been ineffective due to phosphorus forming a complex with aluminium. The addition of lime has mobilised the $\mathrm{P}$ which means ongoing $\mathrm{P}$ application is not immediately necessary as the area is developed.

The failure of all but the lupin and Caucasian clover was dramatic in the third year and driest year. There was no production from balansa clover as it appeared unable to regenerate after seed set in the first year. Also, the regenerating resident vegetation appeared too competitive in this environment, but annual legumes have been used successfully in a slightly lower rainfall environment at Omarama Station (Olykan et al. 2018). The combined mean legume yields of the balansa clover, white clover and lotus plots give an indication of the potential yield from the resident vegetation and the enhancement that has been provided by the introduction of lupins. The failure of lotus to persist in the environment was unexpected because it has previously been recommended for similar environments (Keoghan et al. 1989).

\section{On-farm application}

Like many South Island high-country properties Glenmore Station noticed a lack of production from oversown country after large initial responses in 1970s and 1980s. This land is used for lambing and autumn grazing so is an integral component of the farming system. The experimental results meant the production constraints of the land were understood which gave confidence to develop it.

Initially, in 2011, 20 ha were autumn-sprayed with glyphosate and metsulfuron. This ground was left fallow over winter and the dead browntop (Agrostis capillaris) was burnt the following spring. This promoted regrowth that was sprayed again in early November with glyphosate. Ryecorn (Secale cereale) was drilled in January 2012 at a rate of $100 \mathrm{~kg} / \mathrm{ha}$ with $100 \mathrm{~kg} / \mathrm{ha}$ of Cropmaster 20 (18.8N; 10P; 0K; 12S) and grazed with merino ewes over the autumn and following spring. Two applications of urea $(46 \% \mathrm{~N})$ at $80 \mathrm{~kg} / \mathrm{ha}$ were applied after each autumn graze. This was then sprayed out mid-November so moisture could be saved until the following January (2013) when a second crop of ryecorn was drilled. The grazing management was the same as the previous year, however, this crop was sprayed out earlier in mid-October to ensure moisture was available for the establishment of the permanent lupin-based pasture.

In December 2013 this area was drilled with $6 \mathrm{~kg} / \mathrm{ha}$ 'Russell' lupin, $4 \mathrm{~kg} / \mathrm{ha}$ of 'Endura' Caucasian clover, 2 kg/ha 'Tekapo' cocksfoot (Dactylis glomerata) and 100 $\mathrm{kg} / \mathrm{ha}$ Cropmaster 20 fertiliser. Grazing was delayed until May to give time for all plants to establish.

During the ryecorn development the area was fenced into 5 ha paddocks. Ewes were set-stocked (10/ha) from the start of lambing (mid-October). Once the lambs were old enough, a 25-day rotation commenced. The ewes did not eat the lupins until early December when they started to flower probably due to the alkaloid content (Wink 1987). This meant the tall lupins provided excellent lambing shelter. Lupins contain alkaloids that belong to the 
quinolizidine group (Wink 1987) which is responsible for forage bitterness. In mature plants, these alkaloids tend to accumulate in the seeds, pods, stems and roots (Gladstones 1970; Wink \& Hartmann 1981; Williams \& Harrison 1983; Wink 1987). Williams \& Harrison (1983) found that $80-95 \%$ of total plant alkaloid was present in the ripe seed. These alkaloids work as a defence mechanism preventing excessive grazing by ruminants, particularly during seed formation and ripening (Gladstones 1970). During set-stocking the ewes ate the cocksfoot and Caucasian clover. On the first rotation they ate the lupin flowers and on the second the leaves. Cattle were introduced in earlyDecember to control the cocksfoot which was going to seed. Once lambs were weaned (early-February) big mobs of ewes were used to eat any remaining lupins to stop them from going to seed and becoming unpalatable. With autumn rains the lupin grows again into a palatable plant. Frosts do not damage the plants, so this feed can be taken into June with no loss of yield.

Another 100 ha have subsequently been developed using the same method. However, applying $100 \mathrm{~kg} /$ ha of urea in the first spring helped to break down the browntop thatch, and improve the initial ryecorn yield. Given the time it takes for the Caucasian clover to spread, there was bare ground between lupin plants which was being infested with horehound (Marrubium vulgare). To overcome this problem, sowing rates were changed to $8 \mathrm{~kg} / \mathrm{ha}$ lupin, $4 \mathrm{~kg} / \mathrm{ha}$ Caucasian, 3 $\mathrm{kg} / \mathrm{ha}$ cocksfoot and $4 \mathrm{~kg} / \mathrm{ha}$ prairie grass (Bromus willdenowii).

Historically, on this type of land ewes are stocked at $2.5-3 /$ ha for lambing. Ewes generally lose weight over lambing and as a result have light lambs at weaning. In a normal year there is not a lot of autumn pasture production. The improved lupin based pastures have allowed stocking rate to triple, and ewes have maintained weight over lambing with heavier lambs at weaning. In addition, standing feed can be taken into the autumn and early winter.

\section{Conclusions}

'Russell' lupin was the most dominant and persistent amongst sown legumes in this experiment. The persistence of other legume species at this site was low. Lucerne showed a high plant mortality and poor nodulation even when $4 \mathrm{t} / \mathrm{ha}$ of lime was surface applied. Lotus pedunculatus failed to persist and balansa clover did not regenerate in sufficient plant numbers. White clover survived during a wet summer, but the normal dry summers suppressed its yield in this environment. Results of this experiment suggest 'Russell' lupin and Caucasian clover as the main species to be sown in this acidic high Al soil, without lime application. Based on the outcome of this experiment, about 120 ha of Glenmore Station has been sown with 'Russell' lupin, cocksfoot, and Caucasian clover.

\section{ACKNOWLEDGEMENTS}

NZ Merino Ltd and Miss E.L. Hellaby (Indigenous Grasslands Research Trust) provided funding. Lincoln University students and technical staff provided assistance in the field and laboratory.

\section{REFERENCES}

Allan, B.E.; Keoghan, J.M. 1994. More persistent legume and grass species for oversown tussock country. Proceedings of the New Zealand Grasslands Association 56: 143-147.

Anderson, D.; Anderson L.; Moot, D.J.; Ogle, G.I. 2014. Integrating lucerne (Medicago sativa L.) into a high country merino system. Proceedings of the New Zealand Grassland Association 76: 29-34.

Andrews, M.; Jack, D.; Dash, D.; Brown, S. 2015. Which rhizobia nodulate which legumes in New Zealand soils? Journal of New Zealand Grasslands 77: 281-286.

Berenji, S.; Moot, D.J.; Moir, J L.; Ridgway, H.J. 2015. Lucerne dry matter and N-fixation, when sown with or without lime and inoculant. Journal of New Zealand Grasslands 77: 109-116.

Berenji, S.; Moot, D.J.; Moir, J.L.; Ridgway, H.J.; Rafat, A. 2017. Dry matter yield, root traits, and nodule occupancy of lucerne and Caucasian clover when grown in acidic soil with high aluminium concentrations. Plant and Soil 416: 227-241.

Black, A.D.; Moot, D.J.; Lucas, R.J. 2002. Seedling development and growth of white clover, Caucasian clover and perennial ryegrass grown in field and controlled environments. Proceedings of the New Zealand Grassland Association 64: 197-204.

Black, A.D.; Harvey, J.L.; Moir, J.L.; Moot, D.J. 2014a. Caucasian clover responses to fertiliser, lime and rhizobia inoculation at Lake Heron Station, Canterbury. Proceedings of the New Zealand Grassland Association 76: 105-110.

Black, A.D.; Loxton, G.; Ryan-Salter, T.P.; Moot, D.J. 2014b. Sheep performance on perennial lupins over three years at Sawdon Station, Lake Tekapo. Proceedings of the New Zealand Grassland Association 76: 35-40.

Black, A.D.; Ryan-Salter, T.P.; Liu, W.; Moot, D.J.; Hill, G.D.; Andrews, M. 2015. Bradyrhizobia with a distinct nodA gene nodulate Lupinus polyphyllus in New Zealand soils. pp. 45-48. In: Developing lupin crop into a major and sustainable food and feed source. (Ed.). Duranti, M. Proceedings of the XIV International Lupin Conference, 21-26 June 2015. Milan, Italy. 
Caradus, J.R.; Crush, J.R.; Ouyang, L.; Fraser, W. 2001. Evaluation of aluminium-tolerant white clover (Trifolium repens) selections on East Otago upland soils. New Zealand Journal of Agricultural Research 44: 141-150.

Davis, M.R. 1981a. Growth and nutrition of legumes on a high country yellow-brown earth subsoil: I. Phosphate response of Lotus, Trifolium, Lupinus, Astragalus, and Coronilla species and cultivars. New Zealand Journal of Agricultural Research 24: 321332.

Davis, M.R. 1981b. Growth and nutrition of legumes on a high country yellow-brown earth subsoil: II. A comparison of tropical and temperate species. New Zealand Journal of Agricultural Research 24: 333337.

Gladstones, J.S. 1970. Lupins as crop plants. Field Crop Abstracts 23: 123-148.

Harris, A.; Brown, K.; Turner, J.; Johnston, J.; Ryan, D.; Hickey, M. 1973. Some factors affecting pasture growth in Southland. New Zealand Journal of Experimental Agriculture 1: 139-163.

Hendrie, D.L.; Moir, J.L.; Stevens, E.J.; Black, A.D.; Moot, D.J. 2018. Soil pH, exchangeable aluminium and legume yield responses to deep placed lime at Omarama Station. Journal of New Zealand Grasslands 80: 137-144.

Hewitt, A.E. 1992. New Zealand soil classification. DSIR Land Resources Scientific Report 19: 1-110.

Hurst, R.G.M.; Black, A.D.; Lucas, R.J.; Moot, D.J. 2000. Sowing strategies for slow-establishing pasture species on a North Otago dairy farm. Proceedings of the New Zealand Grassland Association 62: 129-135.

Keoghan, J.M.; Fraser, W.J.; Heenan, R.P. 1989. Performance of white clover and lotus cultivars and lines in the East Otago Plateau. Proceedings of the New Zealand Grassland Association 50: 189-196.

Moir, J.L.; Moot, D.J. 2010. Soil pH, exchangeable aluminium and lucerne yield responses to lime in a South Island high country soil. Proceedings of the New Zealand Grassland Association 72: 191-196.

Moir, J.L.; Moot, D.J. 2014. Medium-term soil pH and exchangeable aluminium response to liming at three high country locations. Proceedings of the New Zealand Grassland Association 76: 41-46.

Monk, S.; Moot, D.J.; Belgrave, B.R; Rolston, M.P.; Caradus, J.R. 2016. Availability of seed for hill country adapted forage legumes. Hill Country Symposium. Grassland Research and Practice Series 16: 257-267.

Moorhead, A.J.E.; White, J.G.H.; Jarvis, P.; Lucas, R.J.; Sedcole, R.J. 1994. Effect of sowing method and fertilizer application on establishment and first season growth of Caucasian clover. Proceedings of the New Zealand Grasslands Association 56: 91-95.
Moot, D.J. 2012. An overview of dryland legume research in New Zealand. Crop and Pasture Science 63: 726-733.

Moot, D.J.; Black, A.D.; Moir, J.L.; Lucas, R.J.; Pollock, K.M.; Roux, M.M., Ryan-Salter, T.P.; Berenji, S. 2013. Forage establishment and management in the high country of New Zealand. Report to New Zealand Merino Company Ltd. Lincoln University, 115 pp. http://www.lincoln.ac.nz/PageFiles/23855/2013-0601 -forage-establishment-and-management-in-thehigh-country-of-New-Zealand.pdf.

Moot, D.J.; Moir, J.L.; Pollock, K.M.; Berenji, S. 2015. Forage establishment and management in the high country of New Zealand. Report to New Zealand Merino Company Ltd. Lincoln University, $60 \mathrm{pp}$. http://www.lincoln.ac.nz/PageFiles/23855/New\%20 Zealand $\% 20$ Merino\% $\quad$ 20Company\%20Report $\% 20$ 2015.pdf

Moot, D.J.; Pollock, K.M. 2014. Perennial lupin establishment and yield when sown at five different rates at Glenmore Station, Lake Tekapo. Proceedings of the New Zealand Grassland Association 76: 5359.

Moot, D.J.; Scott, W.R.; Roy, A.M.; Nicholls, A.C. 2000. Base temperature and thermal time requirements for germination and emergence of temperate pasture species. New Zealand Journal of Agricultural Research 43: 15-25.

Olykan S.T.; Lucas, R.J.; Teixeira, C.S.; Subtil, R.A.; Moot, D.J. 2018. Establishment, production and regeneration of subterranean clovers in the Mackenzie Basin, New Zealand. Journal of New Zealand Grasslands 80: 97-106.

Ryan-Salter, T.P.; Black, A.D.; Andrews, M.; Moot, D.J. 2014. Identification and effectiveness of rhizobial strains that nodulate Lupinus polyphyllus. Proceedings of the New Zealand Grassland Association 76: 61-66.

Scott, D. 1989. Perennial or Russell lupin: a potential high country pasture legume. Proceedings of the New Zealand Grassland Association 50: 203-206.

Scott, D.; Round-Turner, N.L.; Ryde, D.H. 1995. A guide to pastures and pasture species for the New Zealand high country. Grassland Research and Practice Series 4.42 pp.

Scott, D. 1998. Sixteen years of Caucasian clover under contrasting managements. Proceedings of the New Zealand Grassland Association 60: 115-118.

Scott, D. 2001. Sustainability of New Zealand high country pastures under contrasting development inputs 7. Environmental gradients, plant species selection, and diversity. New Zealand Journal of Agricultural Research 44: 59-90.

Thomas, R.G. 2003. Comparative growth forms of dryland forage legumes. Legumes for Dryland 
Pastures. Grassland Research and Practice Series 11: 19-26.

Wardle, P. 2016. War of the lupins. New Zealand Geographic 137. Accessed: 29th May 2018. https:// www.nzgeo.com/stories/war-of-the-lupins.

Whitley, A.E.; Almond, P.C.; Moir, J.L.; Giona Bucci, M.; Nelson, J.; Moot, D.J. 2018. A field survey of soil $\mathrm{pH}$ and extractable aluminium in the Ashburton Lakes Catchment, Canterbury, New Zealand. Journal of New Zealand Grasslands 80: 149-154.

Williams, W.; Harrison, J.E.M. 1983. Alkaloid concentration during development in three Lupinus species and the expression of genes for alkaloid biosynthesis in seedlings. Phytochemistry 22: 85-90. Wink, M. 1987. Quinolizidine alkaloids: biochemistry, metabolism, and function in plants and cell suspension cultures. Planta Medica 53: 509-514.

Wink, M.; Hartmann, T. 1981. Sites of enzymatic synthesis of quinolizidine alkaloids and their accumulation in Lupinus polyphyllus. Zeitschrift für Pflanzenphysiologie 102: 337-344.

Wigley, K.; Ridgway, H.J.; Humphries, A.W.; Ballard, R.A; Moot, D.J. 2018. Increased lucerne nodulation in acid soils with Sinorhizobium meliloti and lucerne tolerant to low $\mathrm{pH}$ and high aluminium. Crop and Pasture Science (In press). 
